J. Clin. Chem. Clin. Biochem.

Vol. 24, 1986, pp. 445-449

(C) 1986 Walter de Gruyter \& Co.

Berlin - New York

\title{
Determination of Serum Triglycerides by Capillary On-Column Gas Chromatography
}

\author{
By J. W. I. Brunnekreeft and B. Leijnse \\ Department of Clinical Chemistry, University Hospital Dijkzigt and Department of Chemical Pathology, \\ Erasmus University, Rotterdam, The Netherlands
}

(Received November 29, 1985/February 21, 1986)

Summary: We report an accurate method, based on capillary on-column gas chromatography, for determining triglycerides in human serum. After serum extraction and chemical hydrolysis, glycerol is directly measured by gas chromatography (GC). With our extraction method no free glycerol is extracted from serum. The accuracy of this method was compared with that of a method based on the original procedure of Carlson (J. Atheroscler. Res. 3, 334-336 (1963)) and which is standardized by the Centers for Disease Control (CDC, Atlanta, U.S. A.).

Orthogonal regression analysis of the GC method (y) and the CDC reference method (x) resulted in $y=0.996 x+0.000$ with a correlation coefficient of 0.999 . The variances of analytical data, collected over a two month period showed that, for the GC method, the within-day coefficient of variation (CV) was $<1.43 \%$; the between-day CV $<1.35 \%$. The data for the CDC method were $<3.36 \%$ (within-day) and $<6.38 \%$ (between-days).

The CDC method is linear up to $3.7 \mathrm{mmol} / \mathrm{l}$ and the $\mathrm{GC}$ method to $22 \mathrm{mmol} / \mathrm{l}$.

\section{Bestimmung der Triglyceride im Serum durch Kapillar-Gas-Chromatographie auf der Säule}

Zusammenfassung: Wir beschreiben eine genaue Methode zur Bestimmung von Triglyceriden in menschlichem Serum auf der Grundlage der Kapillargaschromatographie auf der Säule.

Nach der Extraktion des Serums und chemischer Hydrolyse wird Glycerin durch Gaschromatographie (GC) direkt gemessen. Mit unserer Extraktionsmethode wird kein freies Glycerin aus Serum extrahiert. Die Richtigkeit dieser Methode wurde mit einer Methode verglichen, die auf der Originalmethode von Carlson (J. Atheroscler. Res. 3, 334-336 (1963)) beruht und die durch die Centers for Disease Control (CDC, Atlanta, USA) standardisiert ist. Eine orthogonale Regressionsanalyse der GC-Methode (y) und der CDCReferenzmethode $(x)$ ergab $y=0,996 x+0,000$ mit einem Korrelationskoeffizienten von 0,999 . Die Variabilität-der über eine Periode von zwei Monaten gesammelten analytischen Daten zeigte für die GC-Methode einen Variationskoeffizienten in der Serie von $<1,43 \%$, von Tag zu Tag $<1,35 \%$. Die Werte für die CDCMethode waren $<3,36 \%$ in der Serie und $<6,38 \%$ von Tag zu Tag.

Die CDC-Methode ist linear bis zu 3,7 mmol/1, die GC-Methode bis zu $22 \mathrm{mmol} / \mathrm{l}$.

\section{Introduction}

Usually triglycerides are determined in serum and plasma by hydrolysing the triglycerides and determining the released glycerol enzymatically. These enzymatic methods are not yet perfected, and blanking for free glycerol is a difficult problem. Therefore chemical methods are used as comparative methods. At present there is no officially recognized reference method (1). 
The Centers for Disease Control (CDC, Atlanta, U.S.A.) have standardized a modification of the method of Carlson (2). The principle of this method is that of the classical method of Van Handel \& Zilversmit (3). Lipids are extracted from serum or plasma with chloroform-methanol, followed by removal of phospholipids with silicic acid from the extract, hydrolysis of the triglycerides with ethanolic potassium hydroxide and determination of the released glycerol with chromotropic acid. The CDC has certified this method for use in our laboratory as a potential reference method within the WHO Cooperative Cholesterol and Triglycerides Standardization Programme and the CDC-NHBLI Lipid Standardization Programme. It is a laborious method, especially the removal of the phospholipids and free glycerol with silicic acid. Moreover the precision of the determination of glycerol with chromotropic acid is not very satisfactory.

We replaced the chromotropic acid method by oncolumn gas chromatography, and to avoid the adsorption step with silicic acid we used a more selective extraction procedure.

We compared our GC-method with the CDCmethod.

\section{Materials and Methods}

Glassware and sampling device

We used an $100 \mathrm{ml}$ certified class A volumetric flask for preparing calibration solutions.

For hexane, we used $6 \mathrm{ml}$ volumetric certified class A pipettes; the pipetting precision was checked by sampling hexane ten times and weighing the sample, which resulted in a coefficient of variation of $0.12 \%(\mathrm{CV})$. All other sampling was done with SMI displacement pettors (Scientific Manufacturing Industries Inc.). Serum $(0.5 \mathrm{ml})$ sampling was gravimetrically checked ten times.

The precision (CV) was $0.21 \%$. All other sampling was gravimetrically checked and the precision (CV) was always $<0.14 \%$.

All tubes $(13 \times 105 \mathrm{~mm})$ were screw-capped with teflon inlayers. Hamilton 701 SN needles (Bonaduz, Switzerland) were used for on-column injection.

\section{Standard and reagents}

Glycerol standards were made in analytical grade ethanol. Glycerol (anhydrous) was purchased from J. T. Baker Chemical Co. (Phillipsburg, U.S. A.). The internal standard, meso-erythritol was purchased from Merck (Darmstadt, F. R. G.) and the stock solution was made in ethanol at a concentration of $1000 \pm 1 \mathrm{mg} / \mathrm{l}$. A $5000 \mathrm{mg} / \mathrm{l}$ triolein standard solution in saline was obtained from Sigma (St. Louis, U.S. A.). Solution C was made by adding $2.1 \mathrm{ml}$ hydrochloric acid $(370 \mathrm{~g} / \mathrm{kg})$ and $5 \mathrm{ml}$ meso-erythritol stock solution to $90 \mathrm{ml}$ ethanol. Hydrochloric acid was used to neutralize the $\mathrm{KOH}$, and meso-erythritol was added as internal standard.

The silylation reagent Trisil-BSA in DMF, packed under nitrogen, was purchased from Pierce Chemical Co. (Rockford, Illinois, U.S.A.). Potassium hydroxide was purchased from Rie- del-de Haen (Hannover, F. R. G.). Ethanolic potassium hydroxide was made by dissolving $19 \mathrm{~g}$ potassium hydroxide in 100 $\mathrm{ml}$ demineralized water; from this solution $6 \mathrm{ml}$ were diluted with ethanol to a final volume of $100 \mathrm{ml}$. All other reagents were from Merck (Darmstadt, F. R. G.).

Sample preparation for GLC i,

Sera were directly assayed or stored at $-20^{\circ} \mathrm{C}$ until use. All mixing was done on a Vortex mixer.

To $3 \mathrm{ml}$ methanol in screw-capped tubes, $0.5 \mathrm{ml}$ serum was added drop by drop and vortex-mixed for $10 \mathrm{~s}$. Then $6 \mathrm{ml}$ hexane was added and all tubes were stoppered and mixed for $15 \mathrm{~s}$. All tubes were placed in a water bath at $60^{\circ} \mathrm{C}$. After 20 min incubation all tubes were again mixed for $1 \mathrm{~min}$. The precipitate in the methanol-layer was centrifuged (1200 g, $5 \mathrm{~min}$ ) and $3 \mathrm{ml}$ of the hexane supernatant was transferred to new tubes. The hexane supernatant was evaporated in vacuo at $38 \pm 2^{\circ} \mathrm{C}$, for $1 \mathrm{~h}, 45 \mathrm{~min}$.

Glycerol standards in ethanol $(0.5 \mathrm{ml})$ were also evaporated under the same conditions. Alcoholic potassium hydroxide $(1 \mathrm{ml})$ was added to the residues and mixed for $15 \mathrm{~s}$.

All tubes were capped and placed in a water bath at $70^{\circ} \mathrm{C}$ for $30 \mathrm{~min}$. After cooling the tubes to room temperature, $2 \mathrm{ml}$ of solution $C$ were added and mixed for $1 \mathrm{~min}$. The potassium chloride precipitate was sedimented by centrifugation $(1200 \mathrm{~g}$, 5 min).

One $\mathrm{ml}$ of the supernatant was evaporated in vacuo at $38 \pm$ $2^{\circ} \mathrm{C}$ for $1 \mathrm{~h}, 30 \mathrm{~min}$. After cooling the tubes to room temperature, $150 \mu \mathrm{l}$ Trisil-BSA were added to the residues and directly mixed for $15 \mathrm{~s}$. All tubes were centrifuged $(1200 \mathrm{~g}, 1 \mathrm{~min})$ then placed in an oven at $50^{\circ} \mathrm{C}$ for $10 \mathrm{~min}$. After cooling to room temperature, $1.5 \mathrm{ml}$ hexane was added and mixed for $1 \mathrm{~min}$. Finally all tubes were centrifuged $(1200 \mathrm{~g}, 1 \mathrm{~min})$. From the hexane-layer, $0.5 \mu \mathrm{l}$ was directly injected on-column.

\section{Gas chromatographic conditions}

We used a gas chromatograph Model Fractovap 4160 equipped with a semi-automated on-column injector and flame ionization detector, all from Carlo Erba (Milan, Italy).

The column was a fused silica OV-1 capillary column (15 $\mathrm{m} \times$ $0.32 \mathrm{~mm}$ ) with a film thickness of $0.3 \mu \mathrm{m}$.

The carrier gas was ultra-pure helium and the inlet pressure was 0.7 bar $(70.72 \mathrm{kPa})$. The volume of the injected sample was $0.5 \mu \mathrm{l}$. The temperature of the injector was $80^{\circ} \mathrm{C}$, and this temperature was held for $3 \mathrm{~min}$ after injection. The oven temperature was then programmed to increase to $260^{\circ} \mathrm{C}$ at $15^{\circ} \mathrm{C} / \mathrm{min}$; then the temperature was held for $7 \mathrm{~min}$. The detector temperature was $300^{\circ} \mathrm{C}$.

The glycerol concentrations were calculated by comparing the peak area ratio glycerol : erythritol.

From 3 standards and a blank, a linear regression analysis was made. The areas of the peaks were digitalized by a reporting data processor Chromatopac C-RIB (Shimadzu Corp. Tokyo, Japan).

\section{Recovery and linearity}

Recovery was checked by adding $100 \mu$ l of solution A or B to three serum pools.

Solution A was made by dissolving $455 \mathrm{mg}$ tripalmitin in 100 $\mathrm{ml}$ hexane. Solution B was a triolein solution $(5000 \mathrm{mg} / \mathrm{l})$ in saline purchased from Sigma (St. Louis, U.S. A.)

We also mixed samples with known triglyceride contents, determined by our GC-method.

Linearity was evaluated by diluting a patient sample several times. 


\section{Results}

\section{Measured accuracy}

We compared the results of our gas-liquid chromatographic method with the data from the CDC-reference method. We evaluated two CDC pools with certified values. The data are presented in table 1 .

\section{Precision}

The within-run and between-run precision of the CDC-reference method and the GC method was evaluated by analysing patient pools.

The between-run precision was evaluated by measuring pooled serum in duplicate on 10 different days in a period of three months. The data are shown in table 2 .

\section{Recovery and linearity}

Recovery experiments were done as described in Materials and Methods. The results are shown in table 3 .

Linearity was evaluated as described in Materials and Methods. The results are shown in figure 1.
Tab. 1. Accuracy and precision of CDC method and the GC method compared.

\begin{tabular}{|c|c|c|c|c|c|c|}
\hline \multirow[t]{2}{*}{$\begin{array}{l}\text { Samples } \\
\mathbf{n}=9\end{array}$} & \multicolumn{2}{|l|}{$\begin{array}{l}\text { Certified } \\
\text { value }\end{array}$} & \multicolumn{2}{|c|}{$\begin{array}{l}\text { CDC reference } \\
\text { method }\end{array}$} & \multicolumn{2}{|c|}{ GC method } \\
\hline & [mmol/1] & (SD) & $\begin{array}{l}\text { Mean } \\
{[\mathrm{mmol} / \mathrm{l}]}\end{array}$ & $\begin{array}{l}\mathrm{CV} \\
{[\%]}\end{array}$ & $\begin{array}{l}\text { Mean } \\
{[\mathrm{mmol} / \mathrm{l}]}\end{array}$ & $\begin{array}{l}\mathrm{CV} \\
{[\%]}\end{array}$ \\
\hline $\begin{array}{l}\text { CDC } \\
\text { pool } 1\end{array}$ & 1.58 & $(0.11)$ & 1.57 & 3.18 & 1.53 & 0.98 \\
\hline $\begin{array}{l}\text { CDC } \\
\text { pool } 2\end{array}$ & 2.94 & $(0.15)$ & 2.94 & 3.06 & 2.95 & 1.01 \\
\hline
\end{tabular}

Tab. 2. Precision of the CDC method and the GC method compared.

\begin{tabular}{|c|c|c|c|c|}
\hline & \multicolumn{2}{|c|}{ CDC reference method } & \multicolumn{2}{|c|}{ GC method } \\
\hline & $\begin{array}{l}\text { Mean } \\
{[\mathrm{mmol} / \mathrm{l}]}\end{array}$ & $\begin{array}{l}\mathrm{CV} \\
{[\%]}\end{array}$ & $\begin{array}{l}\text { Mean } \\
{[\mathrm{mmol} / 1]}\end{array}$ & $\begin{array}{l}\mathrm{CV} \\
{[\%]}\end{array}$ \\
\hline \multicolumn{5}{|c|}{$\begin{array}{l}\text { Within-run } \\
\mathrm{n}=10\end{array}$} \\
\hline $\begin{array}{l}\text { Pool } 1 \\
\text { Pool } 2 \\
\text { Pool } 3\end{array}$ & $\begin{array}{r}0.47 \\
-1.57 \\
2.94\end{array}$ & $\begin{array}{l}6.38 \\
3.18 \\
3.06\end{array}$ & $\begin{array}{l}0.49 \\
1.53 \\
2.95\end{array}$ & $\begin{array}{l}1.43 \\
0.98 \\
1.02\end{array}$ \\
\hline \multicolumn{5}{|c|}{$\begin{array}{l}\text { Between-run } \\
\mathrm{n}=10\end{array}$} \\
\hline $\begin{array}{l}\text { Pool A } \\
\text { Pool B }\end{array}$ & $\begin{array}{l}1.49 \\
0.86\end{array}$ & $\begin{array}{l}3.36 \\
2.32\end{array}$ & $\begin{array}{l}1.46 \\
0.81\end{array}$ & $\begin{array}{l}1.03 \\
1.35\end{array}$ \\
\hline
\end{tabular}

Tab. 3. Recovery of GC method.

\begin{tabular}{|c|c|c|c|c|c|c|}
\hline & \multirow[t]{2}{*}{ Basic value } & \multirow[t]{2}{*}{ Calculated } & \multicolumn{2}{|l|}{ Observed } & \multicolumn{2}{|c|}{ Recovery } \\
\hline & & & $\begin{array}{l}\text { Mean } \\
{[\mathrm{mmol} / \mathrm{l}]}\end{array}$ & $\begin{array}{l}\mathrm{CV} \\
{[\%]}\end{array}$ & $\begin{array}{l}\text { Mean } \\
{[\%]}\end{array}$ & $\begin{array}{l}\mathrm{CV} \\
{[\%]}\end{array}$ \\
\hline \multicolumn{7}{|l|}{$\begin{array}{l}\text { Solution } A \\
\mathrm{n}=4\end{array}$} \\
\hline $\begin{array}{l}\text { Serum I } \\
\text { Serum II } \\
\text { Serum III }\end{array}$ & $\begin{array}{l}0.475 \\
1.339 \\
4.033\end{array}$ & $\begin{array}{l}1.598 \\
2.462 \\
5.156\end{array}$ & $\begin{array}{l}1.605 \\
2.47 \\
5.158\end{array}$ & $\begin{array}{l}0.68 \\
0.82 \\
0.24\end{array}$ & $\begin{array}{l}100.58 \\
100.69 \\
100.49\end{array}$ & $\begin{array}{l}0.97 \\
1.71 \\
0.77\end{array}$ \\
\hline \multicolumn{7}{|l|}{$\begin{array}{l}\text { Solution } B \\
\mathrm{n}=4\end{array}$} \\
\hline $\begin{array}{l}\text { Serum I } \\
\text { Serum II } \\
\text { Serum III }\end{array}$ & $\begin{array}{l}0.475 \\
1.339 \\
4.033\end{array}$ & $\begin{array}{l}1.601 \\
2.465 \\
5.159\end{array}$ & $\begin{array}{l}1.605 \\
2.461 \\
5.156\end{array}$ & $\begin{array}{l}1.22 \\
0.45 \\
0.17\end{array}$ & $\begin{array}{r}100.35 \\
99.62 \\
99.74\end{array}$ & $\begin{array}{l}1.74 \\
0.99 \\
0.78\end{array}$ \\
\hline
\end{tabular}

Mixing experiments

\begin{tabular}{|c|c|c|c|}
\hline $\begin{array}{l}\text { Mixed } \\
{[\mathrm{mmol} / \mathrm{l}]}\end{array}$ & $\begin{array}{l}\text { Expected } \\
\text { value } \\
\text { [mmol/1] }\end{array}$ & $\begin{array}{l}\text { Measured } \\
{[\mathrm{mmol} / \mathrm{l}]}\end{array}$ & $\begin{array}{l}\text { Recovery } \\
{[\%]}\end{array}$ \\
\hline \multirow[t]{2}{*}{$\begin{array}{l}0.62+1.54 \\
1.54+2.90 \\
1.54+4.48 \\
2.90+4.48\end{array}$} & $\begin{array}{l}1.08 \\
2.22 \\
3.01 \\
3.69\end{array}$ & $\begin{array}{l}1.07 \\
2.22 \\
2.99 \\
3.67\end{array}$ & $\begin{array}{c}99.07 \\
100 \\
99.34 \\
99.46\end{array}$ \\
\hline & & Mean & $99.47 \pm 0.39$ \\
\hline
\end{tabular}

\section{Free glycerol}

In order to check if there was any free glycerol extracted by our method, we dissolved $33.0 \mathrm{mg}$ glycerol in $0.5 \mathrm{ml}$ saline (i. e. $358 \mathrm{mmol} / \mathrm{l}$ ) and this was treated as all other samples. The resulting chromatogram did not differ from a blank, as can be seen in figure 2. The existence of a little peak in the blank is probably due to the presence of some glycerol in the potassium hydroxide (4). 


\section{Method comparison}

We evaluated data from 37 patient sera in a two month period and compared the gas chromatographic method (GC) (y) with the Carlson method (x), certified by CDC.

The analytical range of triglycerides in the patient sera was $0.23-3.04 \mathrm{mmol} / 1$.

A graphic representation of the orthogonal regression (5) analysis of both methods is shown in figure 3.

The data were subjected to statistical analysis including the Wilcoxon matched-pairs rank test and the Student t-test. From the Wilcoxon matched-pairs rank test it was concluded that both methods were not significantly different $(p<0.01)$.

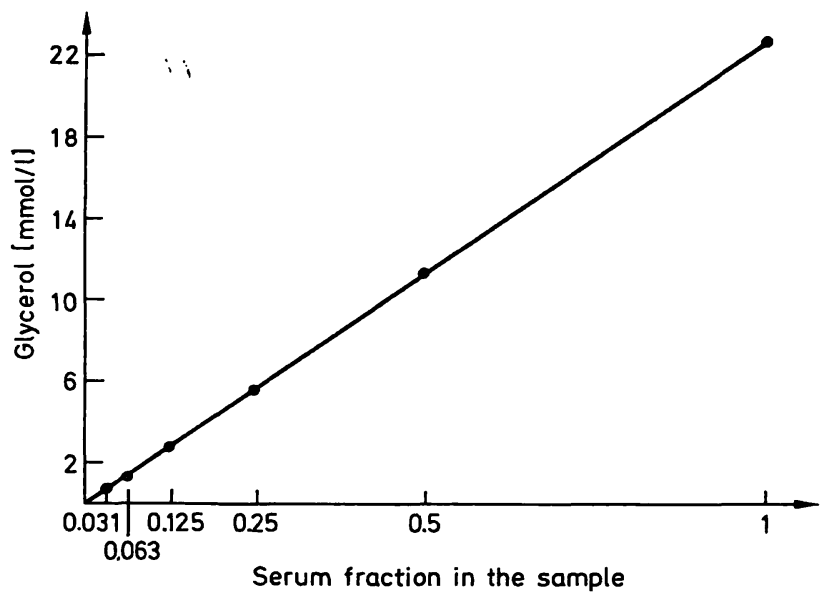

Fig. 1. Evaluation of the linearity of the assay with various dilutions of a patient sample with saline. A correlation was found of $r=0.9999$.

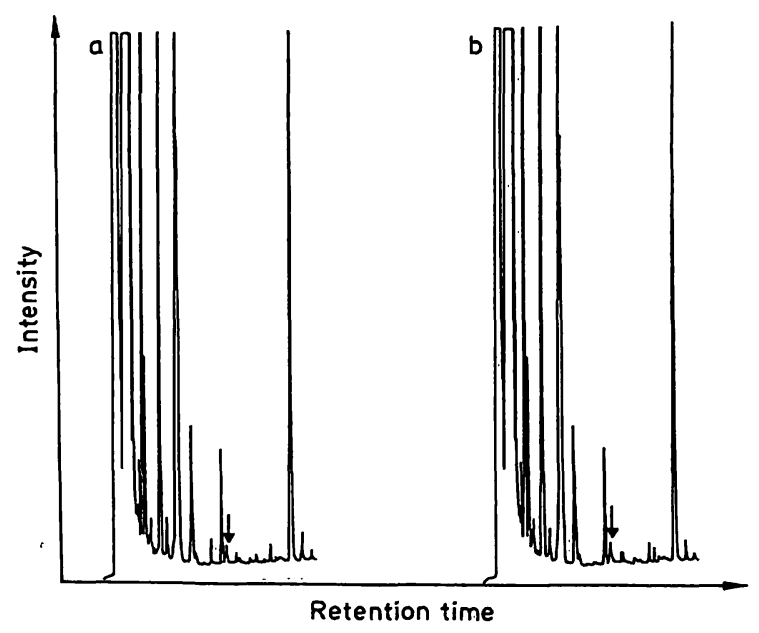

Fig. 2. Comparison of blank (a) versus free glycerol (b) chromatogram. The arrows indicate a "glycerol impurity" of $\mathrm{KOH}(4)$.
The mean difference was $-0.0010 \mathrm{mmol} / 1$ and the SEM was $0.0044 \mathrm{mmol} / \mathrm{l}$, and according to the $S t u$ dent $\mathrm{t}$ test we concluded that the results from the two methods are not significantly different.

A typical chromatogram is shown in figure 4; the retention times were reproducible within $0.01 \mathrm{~min}$. Except for erythritol and glycerol, no peaks were identified.

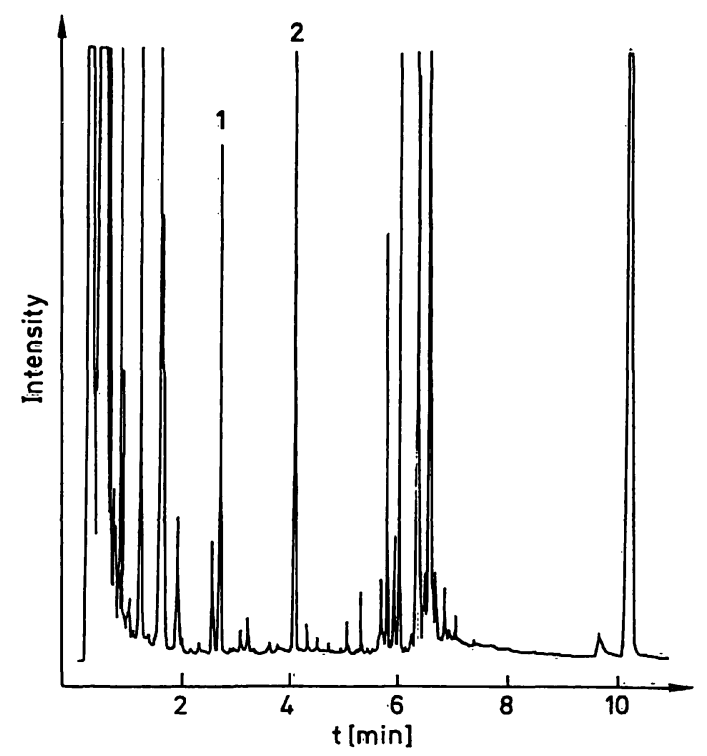

Fig. 3. Gas-liquid chromatogram of glycerol (1); Erythritol (2) was used as internal standard as described in materials and methods.

No further peaks were identified.

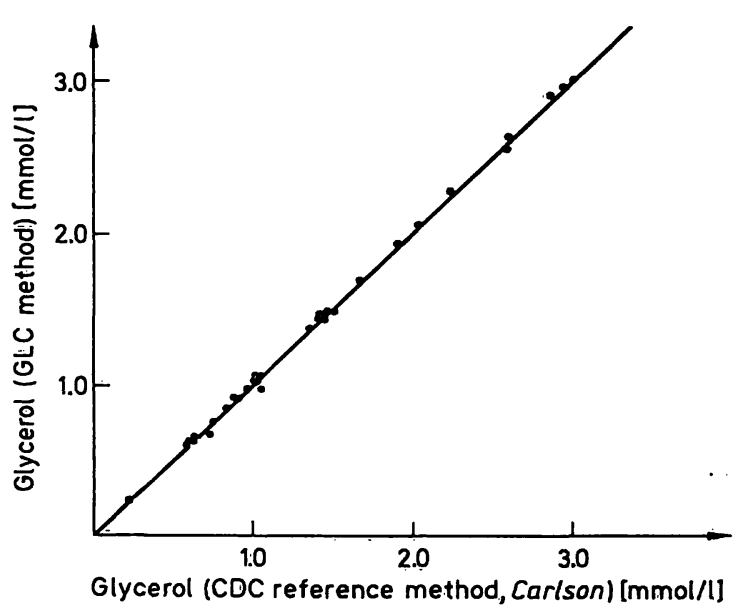

Fig. 4. Comparison of the CDC reference method (x) with our GC method (y). The calculated orthogonal regression line is shown.

$\mathrm{n}=37$

$y=0.996 x+0.0000$

$\mathrm{r}=0.999$

mean $\mathrm{x}=1.426 \mathrm{mmol} / \mathrm{l}$

mean $\mathrm{y}=1.420 \mathrm{mmol} / 1$

$s_{\mathrm{a}}=0.0061$

$s_{b}=0.0097$ 


\title{
Flavins and Flavoproteins
}

\section{Proceedings of the Eighth International Symposium Brighton, England, July 9-13, 1984}

\author{
Editors R. C. Bray ·P. C. Engel - S. G. Mayhew
}

1984. $17 \mathrm{~cm} \times 24 \mathrm{~cm}$. XXXIV, 923 pages. Numerous illustrations. Hardcover. DM 285,-; approx. US \$95.00 ISBN 3110098792

Riboflavin is a vitamin. It is needed in order to make flavoproteins, a large and important group of enzymes involved in oxidation and reduction reactions in living cells.

The proceedings contained in this volume are based on the posters and lectures presented at the Brighton Symposium. They provide an up-to-the-minute account of the rapid advances in this field and review progress in the understanding of how flavoproteins work and also how this knowledge can be applied to medical and industrial problems.

Contents (Main Chapters)

Flavin Chemistry - Flavoprotein Structure - Enzyme Reaction Mechanisms - Modified Flavins in Flavoproteins - Biomedical Aspects - Practical Applications of Flavoprotein Studies - Author Index $\cdot$ Subject Index.

\section{Optical Propenties and Structure of Tetrapyrroles Proceedings of a Symposium, held at the University of Konstanz, West-Germany, August 12-17, 1984}

\section{Editors G. Blauer $\cdot H$. Sund}

1985. $17 \mathrm{~cm} \times 24 \mathrm{~cm}$. XIV, 536 pages. Numerous illustrations.

Hardcover. DM 230,-; approx. US \$76.70 ISBN 3110100541

This volume deals with the aspects of the relation between optical properties, chemical structure and biological function (including medical aspects) of tetrapyrroles.

Contents (Main Chapters)

General - Porphyrins and Metalloporphyrins - Bile Pigments - Chlorophylls · Index of Contributors · Subject Index.

\section{Semiochemistry - Flavors and Pheromones Proceedings - American Chemical Society Symposium Washington D.C., U.S.A., August 1983}

Editors T.E. Acree - D. M. Soderlund

1985. $17 \mathrm{~cm} \times 24 \mathrm{~cm}$. X, 289 pages. Numerous illustrations.

Hardcover. DM 160,-; approx. US \$53.30 ISBN 3110101203

Prices are subject to change without notice

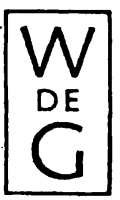

Walter de Gruyter - Berlin - New York 


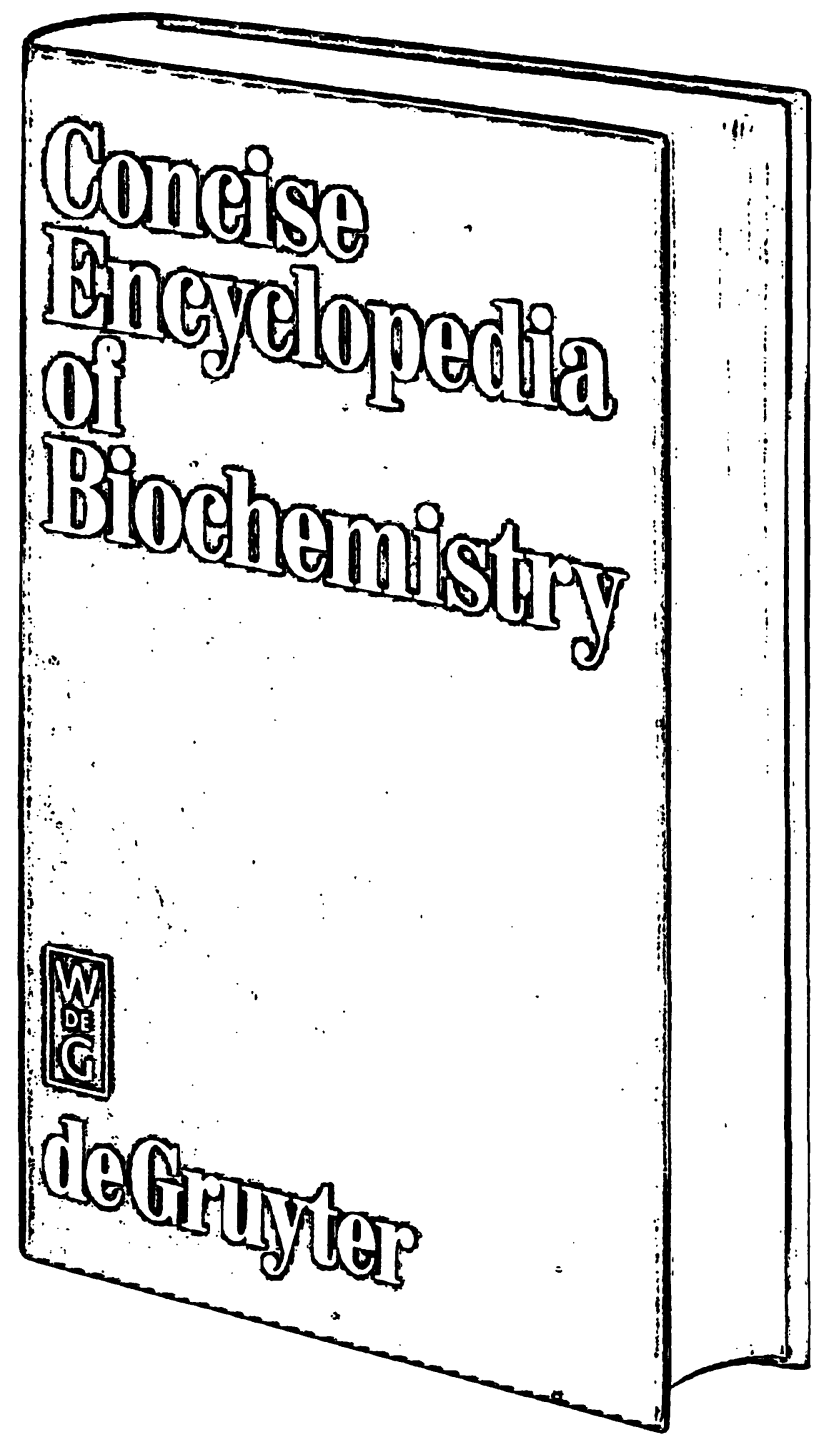

Edited by

Thomas Scott and Mary Brewer

2nd printing with corrections.

1983. $14,0 \mathrm{~cm} \times 21,5 \mathrm{~cm}$.

VI, 519 pages.

Approx. 650 illustrations.

Hardcover. DM 78,-; US \$34.95

ISBN 3110078600

Prices are subject to change without notice

The Concise Encyclopedia of Biochemistry, with more than 4,200 entries, is the foremost collection of current information in this rapidly expanding field. The contents are complemented by numerous structural formulas, metabolic pathways, figures and tables. All those interested in or working in the field of Biochemistry and Biology (Life Sciences), will profit from the information contained in this encyclopedia.

This truly remarkable book is an essential reference for Biochemists, Clinical Chemists, Clinical Biochemists, Clinicians, Medical Researchers and Experimental Biologists. It will also serve as a very useful source of information for students. 


\section{Discussion}

In the comparative methods (potential reference methods) for triglycerides, glycerol is released-by saponification with alcoholic potassium hydroxide. Glycerol is then oxidized to form aldehyde, which is measured colorimetrically after reaction with chromotropic acid (Eegriwe's reaction) or is measured colorimetrically or fluorometrically after reaction with acetylacetone and ammonium acetate (Hantzsch condensation) (1).

We successfully replaced the oxidation of glycerol and the measurement of formaldehyde by direct measurement of the glycerol released by saponification. For this purpose we used capillary on-column gas chromatography after derivatization. The precision of the GC-method is much better than the colorimetric method (tab. 2).

Blanking for free glycerol is a difficult problem in the quantitative analysis for triglycerides. Ter Welle (6) reported a free glycerol concentration of 0.07 $\mathrm{mmol} / 1-2.0 \mathrm{mmol} / \mathrm{l}$. It is assumed that silicic and/or zeolite removes free glycerol. Soloni (7) used a nonane-isopropanol extraction mixture to avoid the ab-

\section{References}

1. Naito, H. K. (1984) In: Clinical Chemistry (Kaplan, L. A. \& Pesce, A. J., eds.) pp. $1221-1229$.

2. Carlson, L. A. (1963) J. Atheroscler. Res. 3, 334-336.

3. Van Handel, E. \& Zilversmit, B. D. (1957) J. Lab. Clin. Med. 50, 152-157.

4. Willms, B. \& Söling, H. D. (1967) J. Clin. Chem. Clin. Biochem. 5, 276-277. sorption step. But the nonane phase contained 1.5\% of the total phosphorus content of the sample and $6.5 \%$ of the triglyceride were lost during the procedure. We developed an easy, selective extraction method with methanol-hexane, which does not extract free glycerol (fig. 2). We analysed the ethanolic potassium hydroxide solution after hydrolysis for the presence of inorganic phosphate.

We compared our GC method with the CDC-method used in our laboratory as a comparative method. We analysed samples from two CDC pools with certified values, in order to compare the accuracy and the precision of both methods. The results, summarized in table 1 , show that our GC method has the same accuracy as the CDC-method. The precision of the GC-method is much better than the precision of the CDC-method.

We suggest that this GC-method is a suitable alternative to the Carlson method.

\section{Acknowledgement}

The authors wish to thank Dr. G. J.M. Boerma for reading the manuscript and his stimulating comments.

5. Deming, W. E. (1943) In: Statistical Adjustment of Data. John Wiley and Sons, New York, p. 184.

6. Ter Welle, W. F., Baartscheer, T. \& Fiolet, J. W. T. (1984) Clin. Chem. 30, 1102-1103.

7. Soloni, F. G. (1971) Clin. Chem. 17, 529-534.

Drs. J. W. I. Brunnekreeft Department of Clinical Chemistry University Hospital Dijkzigt and Department of Chemical Pathology Erasmus University Rotterdam Dr. Molewaterplein 40 NL-3015 GD Rotterdam 
: 